\title{
Effect of Integrated Nutrient Management and Different Plant Spacing on Tulsi
}

\author{
Bhaba Prashad Kalita*, Prabin Kumar Gogoi, Abhijit Sarma, \\ Iswar Chandra Barua and Borsha Neog
}

Assam Agricultural University, Jorhat (Assam), India

*Corresponding author

\begin{tabular}{|l|}
\hline Ke y w o r d s \\
$\begin{array}{l}\text { Integrated nutrient } \\
\text { management, } \\
\text { Spacing, Tulsi }\end{array}$ \\
\hline Article Info \\
\hline $\begin{array}{l}\text { Accepted: } \\
\text { 15 January } 2018 \\
\text { Available Online: } \\
\text { 10 February } 2018\end{array}$
\end{tabular}

\section{Introduction}

Ocimum under the Lamiaceae family comprises of 63 species alternatively known as basil or Tulsi. It mostly grows in sub tropical zone from sea level to altitude of $1800 \mathrm{~m}$ from Mean Sea Level (MSL). Tulsi as "elixir of life" mentioned in Ayurveda believed to promote longevity of life. In Charak Samhita Tulsi described as a cause for adaptive balancing different process of the body. Ocimum sanctum L. Shyama tulsi is a black pigment tulsi also known as dark tulsi or holy basil. It is native to the Indian sub continent and widespread as a cultivated plant throughout the Southeast Asian tropics. Black 
tulsi is mostly cultivated for religious Vaishnava tradition of Hinduism as a sacred plant. The essential oil found in Tulsi is Eugenol allylbenzene).

(1-hydroxy-2methoxy-4

Ram Tulsi or African Bail Ocimum gratissimum $L$. is a herbaceous plant of lime green pubescent leaves with a strong fragrance and light pungency. This plant is native to Africa and grows in Polynesia, Hawaii, Panama, West indies, Brazil, Bolivia, Nepal and India.

Ayurveda and Siddha traditional medicinal systems Tulsi is used to cure flu, common cold, cough, asthma, bronchitis, hepatic diseases, wound, skin diseases, arthriti, diarrhea and influenza. Pharmacologically Tulsi has been used in anti-stress activity, adaptogenic activity, Immunomodulator, anticancer activity, chemo preventive activity, radio protective activity, antihypertensive and cardio protective activities, Antimicrobial activity, analgesic activity, anti-inflammatory, antipyretic, hepatoprotective activity, Memory enhancer, Antidiabetic, antiulcer, anticataract, antihelmintic effects also have been reported. Black Tulsi is used for the preparation of tea, Ram Tulsi leaves are also being used as vegetables and spices for preparations of different cuisines in south-east Asian countries. The Karbi tribes of Assam ram Tulsi leaves are used as a vegetables and also add with some local pork curries.

If plants are planted in a suitable plant density they can properly utilize the different growth factors (water, air, light and nutrients) and inter or intra specific competition is minimum. Though the yield of Tulsi can be increased by supplying essential nutrients through chemical fertilizers alone but considering the point of sustaining soil health in mind we choose to apply integrated sources of nutrients and as well as it is a medicinal plant we must have to give priority for market value and quality of the crop. Keeping this view investigation of the effect of integrated nutrient management and spacing on growth and yield of Ram Tulsi was carried out.

\section{Materials and Methods}

The field experiment was conducted at the Instruction -cum-Research farm of Assam Agricultural University, Jorhat, summer, 2016. The experiment farm is located at $26^{\circ} 47^{\prime} \mathrm{N}$ latitude and $94^{\circ} 12^{\prime} \mathrm{E}$ longitude at an elevation of 86.6 meters above the MSL. The field selected for the experiment was well levelled and homogeneous fertility. The soil texture of the experimental field was sandy loam and acidic in $\mathrm{pH}$. The climate of Jorhat is subtropical humid. The weekly maximum temperature during crop growing period ranges from $33.6^{\circ} \mathrm{C}$ to $26.5^{\circ} \mathrm{C}$ (mean $31.0^{\circ} \mathrm{C}$ ) and minimum temperature ranges from $26.1^{\circ} \mathrm{C}$ to $20.6^{\circ} \mathrm{C}$ (mean $24.4^{\circ} \mathrm{C}$ ) respectively. The total rainfall received during crop growing period was $1051.3 \mathrm{~mm}$. In this experiment factorial randomized block design was used with 3 replications.The $1^{\text {st }}$ factor included two levels of Tulsi species Black Tulsi Ocimum sanctum $\left(\mathrm{V}_{1}\right)$ and Ram Tulsi Ocimum gratissimum $\left(\mathrm{V}_{2}\right), \quad 2^{\text {nd }}$ factor comprises two levels of plant densities $40 \times 40 \mathrm{~cm}\left(\mathrm{~S}_{1}\right), 50 \times 50 \mathrm{~cm}\left(\mathrm{~S}_{2}\right)$ and third factor included four levels of Integrated nutrient doses - 6ton/ha Vermicompost $\left(\mathrm{F}_{1}\right)$, 20-10-10 $\mathrm{N}-\mathrm{P}_{2} \mathrm{O}_{5}-\mathrm{K}_{2} \mathrm{O} \mathrm{kg} / \mathrm{ha}+3 \mathrm{t} / \mathrm{ha}$ Vermicompost $\left(\mathrm{F}_{2}\right)$, 40-15-15 N-P $\mathrm{O}_{5}-\mathrm{K}_{2} \mathrm{O} \mathrm{kg} / \mathrm{ha}+3 \mathrm{t} / \mathrm{ha}$ Vermicompost $\left(\mathrm{F}_{3}\right)$, 60-20-20 N- $\mathrm{P}_{2} \mathrm{O}_{5}-\mathrm{K}_{2} \mathrm{O}$ $\mathrm{kg} / \mathrm{ha}+3 \mathrm{t} / \mathrm{ha}$ Vermicompost $\left(\mathrm{F}_{4}\right)$. Terminal cuttings of Ram Tulsi with 5-6 nodes and 10$15 \mathrm{~cm}$ length was raised in plastic plates of size $(60 \times 50 \times 15 \mathrm{~cm})$ filled with Soil, sand and FYM under the net house for use as a propagating material. Raising of Black Tulsi is done from seeds which were $1^{\text {st }}$ grown in the nursery bed and then transplanted. Transplanting of 2 months old seedling was done in the $3^{\text {rd }}$ week of April, 2016 in the 
main field. Thereafter irrigation was done as an when required during the dry spell of MayJune. Half doses of Urea and the full dose of Single Super Phosphate, Muriate Of Potash were applied at the time of transplanting. Full doses of Vermicompost were applied 7 days before planting in the dug pits. Remaining half doses of urea were applied in two equal doses at 30, 60 Days after planting (DAP).

Observations were recorded at 30,60 and 90 DAP (final harvest). For the determination of fresh leaf weight at 30, 60 DAP we just randomly selected 3 plant samples from the individual plots and later converted this in to the ratio of tons/ha. At final harvest essential oil was extracted using Clevenger apparatus. The percentage of oil was calculated on volume by weight basis. Calculation of essential oil yield was done by the product of oil content (\%) and yield of fresh leaves at harvest.

\section{Results and Discussion}

\section{Growth attributes}

The growth of plant can be manifested in different ways, Simple to measure the growth is by recording height. Though height is controlled genetically, it can be modified by application of inorganic fertilizers and organic manures. Significantly distinct differences were observed in the plant height up to the harvest period for the two varieties of the tulsi. The highest value of plant height was recorded in Ocimum gratissimum (Ram tulsi). Differences in growth between the species are due to their genetical character. Different spacing could not exert significant influence on the plant height. Similarly, Raina et al., (2013) observed the non significant effect on plant height due to different spacing.

Plant height was found significant influence by different integrated nutrient management treatments. Application of 60-20-20 N-P $\mathrm{O}_{5-}$ $\mathrm{K}_{2} \mathrm{O} \mathrm{kg} / \mathrm{ha}+3 \mathrm{t} / \mathrm{ha}$ Vermicompost $\left(\mathrm{F}_{4}\right)$ resulted maximum height in all stages of growth, which was, however, at par with 4015-15 N-P $\mathrm{O}_{5}-\mathrm{K}_{2} \mathrm{O} \mathrm{kg} / \mathrm{ha}+3 \mathrm{t} / \mathrm{ha}$ Vermicompost $\left(\mathrm{F}_{3}\right)$ and significantly higher than that of $20-10-10 \mathrm{~N}-\mathrm{P}_{2} \mathrm{O}_{5}-\mathrm{K}_{2} \mathrm{O} \mathrm{kg} / \mathrm{ha}+$ $3 \mathrm{t} /$ ha Vermicompost $\left(\mathrm{F}_{2}\right)$ and 6 ton/ha Vermicompost $\left(\mathrm{F}_{1}\right)$. Increase in growth might be due to the gradual increase in doses of $\mathrm{N}$ $\mathrm{P}_{2} \mathrm{O}_{5}-\mathrm{K}_{2} \mathrm{O}$ which increased the uptake of nutrients. These results are line with the reports of Basavaraju et al., (2012).

Increase in number of branches with time up to maturity indicates the indeterminate or perennial character of the species. There was not any significant difference for number of branches per plant between the species in the early stage of their growth. But at harvesting stage, significant difference was seen. Ram Tulsi had more branching than that of black Tulsi. This was also due to the genetic effect of the species. As Ram Tulsi had more vigour and large foliage it produces more branching than Black Tulsi.

Spacing had significant influence on number of branches per plant. Wider spacing $(50 \times 50 \mathrm{~cm})$ had more branching than that of closer spacing $(40 \times 40 \mathrm{~cm})$. It might be due to wider space provided under wider spacing that facilitated more branching.

The effect of different nutrient management practices had significant influence on number of branches per plant. Among the different treatments 60-20-20 N-P $\mathrm{P}_{2}-\mathrm{K}_{2} \mathrm{O} \mathrm{kg} / \mathrm{ha}+$ $3 \mathrm{t} /$ ha Vermicompost $\left(\mathrm{F}_{4}\right)$ resulted highest number of branches per plant, which was statistically at par with $40-15-15 \mathrm{~N}-\mathrm{P}_{2} \mathrm{O}_{5}-\mathrm{K}_{2} \mathrm{O}$ $\mathrm{kg} / \mathrm{ha}+3 \mathrm{t} / \mathrm{ha}$ Vermicompost $\left(\mathrm{F}_{3}\right)$ and significantly higher than that of 20-10-10 N$\mathrm{P}_{2} \mathrm{O}_{5}-\mathrm{K}_{2} \mathrm{O} \mathrm{kg} / \mathrm{ha}+3 \mathrm{t} / \mathrm{ha}$ Vermicompost $\left(\mathrm{F}_{2}\right)$ and 6ton/ha Vermicompost $\left(\mathrm{F}_{1}\right)$ (Table 1-4). 
Table.1 Plant height $(\mathrm{cm})$ of tulsi as influenced by species, Spacing and integrated nutrient management

\begin{tabular}{|c|c|c|c|}
\hline \multirow{2}{*}{\multicolumn{4}{|c|}{$\begin{array}{l}\text { Treatments } \\
\text { Species (V) }\end{array}$}} \\
\hline & & & \\
\hline $\mathrm{V}_{1}$ :Ocimum sanctum & 29.1 & 42.5 & 51.8 \\
\hline $\mathrm{V}_{2}:$ Ocimum grastissium & 42.1 & 60.6 & 75.4 \\
\hline SEd \pm & 1.1 & 1.5 & 1.9 \\
\hline $\mathrm{CD}(\mathrm{P}=\mathbf{0 . 0 5})$ & 2.2 & 3.1 & 3.9 \\
\hline \multicolumn{4}{|l|}{ Spacing (S) } \\
\hline$S_{1}: 40 \mathrm{~cm} X 40 \mathrm{~cm}$ & 35.6 & 50.6 & 63.8 \\
\hline$S_{2}: 50 \mathrm{~cm} X 50 \mathrm{~cm}$ & 35.6 & 52.5 & 63.4 \\
\hline SEd \pm & 1.1 & 1.5 & 1.9 \\
\hline $\mathrm{CD}(\mathrm{P}=\mathbf{0 . 0 5})$ & NS & NS & NS \\
\hline \multicolumn{4}{|l|}{$\begin{array}{l}\text { Integrated Nutrient } \\
\text { Management (F) }\end{array}$} \\
\hline$F_{1}: 6$ ton/ha Vermicompost & 31.0 & 43.2 & 54.5 \\
\hline $\begin{array}{l}\mathrm{F}_{2}: 20-10-10 \mathrm{~N}-\mathrm{P}_{2} \mathrm{O}_{5}-\mathrm{K}_{2} \mathrm{O} \\
\mathrm{kg} / \mathrm{ha}+\mathrm{VC}(3 \mathrm{t} / \mathrm{ha})\end{array}$ & 34.2 & 50.4 & 63.4 \\
\hline $\begin{array}{l}\mathrm{F}_{3}: 40-15-15 \mathrm{~N}-\mathrm{P}_{2} \mathrm{O}_{5}-\mathrm{K}_{2} \mathrm{O} \\
\mathrm{kg} / \mathrm{ha}+\mathrm{VC}(3 \mathrm{t} / \mathrm{ha})\end{array}$ & 37.2 & 54.9 & 66.1 \\
\hline $\begin{array}{l}\mathrm{F}_{4}: \text { 60-20-20 N-P } \mathrm{O}_{5}-\mathrm{K}_{2} \mathrm{O} \\
\mathrm{kg} / \mathrm{ha}+\mathrm{VC}(3 \mathrm{t} / \mathrm{ha})\end{array}$ & 40.1 & 57.8 & 70.2 \\
\hline SEd \pm & 1.6 & 2.2 & 2.7 \\
\hline $\mathrm{CD}(\mathrm{P}=\mathbf{0 . 0 5})$ & 3.2 & 4.4 & 5.5 \\
\hline \multicolumn{4}{|l|}{ Interactions } \\
\hline $\mathrm{V} \times S$ & NS & NS & NS \\
\hline $\mathbf{S} \times \mathbf{F}$ & NS & NS & NS \\
\hline $\mathbf{V} \times \mathbf{F}$ & NS & NS & NS \\
\hline $\mathbf{V} \times S \times F$ & NS & NS & NS \\
\hline
\end{tabular}


Table.2 Number of branches per plant of tulsi as influenced by species, Spacing and integrated nutrient management

\begin{tabular}{|c|c|c|c|}
\hline Treatments & 30 DAP & 60 DAP & 90 DAP \\
\hline \multicolumn{4}{|l|}{ Species (V) } \\
\hline $\mathrm{V}_{1}:$ Ocimum sanctum & 10.2 & 25.1 & 37.5 \\
\hline $\mathrm{V}_{2}$ : Ocimum grastissium & 9.8 & 24.8 & 44.6 \\
\hline SEd \pm & 0.3 & 1.0 & 1.5 \\
\hline $\mathrm{CD}(\mathbf{P}=\mathbf{0 . 0 5})$ & NS & NS & 3.0 \\
\hline \multicolumn{4}{|l|}{ Spacing (S) } \\
\hline$S_{1:} 40 \mathrm{~cm} \mathrm{X} 40 \mathrm{~cm}$ & 9.4 & 23.8 & 39.4 \\
\hline$S_{2}: 50 \mathrm{~cm} X 50 \mathrm{~cm}$ & 10.6 & 26.1 & 42.7 \\
\hline SEd \pm & 0.3 & 1.0 & 1.5 \\
\hline $\mathrm{CD}(\mathrm{P}=\mathbf{0 . 0 5})$ & 0.6 & 2.0 & 3.0 \\
\hline \multicolumn{4}{|l|}{$\begin{array}{l}\text { Integrated Nutrient } \\
\text { Management (F) }\end{array}$} \\
\hline$F_{1}: 6$ ton/ha Vermicompost & 6.4 & 18.9 & 31.6 \\
\hline $\begin{array}{l}\mathrm{F}_{2}: 20-10-10 \mathrm{~N}-\mathrm{P}_{2} \mathrm{O}_{5}-\mathrm{K}_{2} \mathrm{O} \\
\mathrm{kg} / \mathrm{ha}+\mathrm{VC}(3 \mathrm{t} / \mathrm{ha})\end{array}$ & 9.1 & 23.5 & 39.3 \\
\hline $\begin{array}{l}F_{3}: 40-15-15 \mathrm{~N}-\mathrm{P}_{2} \mathrm{O}_{5}-\mathrm{K}_{2} \mathrm{O} \\
\mathrm{kg} / \mathrm{ha}+\mathrm{VC}(3 \mathrm{t} / \mathrm{ha})\end{array}$ & 11.9 & 27.6 & 44.7 \\
\hline $\begin{array}{l}\mathrm{F}_{4}: \text { 60-20-20 N-P } \mathrm{P}_{2}-\mathrm{K}_{2} \mathrm{O} \\
\mathrm{kg} / \mathrm{ha}+\mathrm{VC}(3 \mathrm{t} / \mathrm{ha})\end{array}$ & 12.6 & 29.8 & 48.6 \\
\hline SEd \pm & 0.4 & 1.4 & 2.1 \\
\hline $\mathrm{CD}(\mathbf{P}=\mathbf{0 . 0 5})$ & 0.8 & 2.9 & 4.2 \\
\hline \multicolumn{4}{|l|}{ Interactions } \\
\hline $\mathbf{V} \times S$ & NS & NS & NS \\
\hline $\mathbf{S} \times \mathbf{F}$ & NS & NS & NS \\
\hline $\mathbf{V} \times \mathbf{F}$ & NS & NS & NS \\
\hline $\mathbf{V} \times S \times F$ & NS & NS & NS \\
\hline
\end{tabular}


Table.3 Fresh weight of tulsi leaves (ton/ha) as influenced by species, Spacing and integrated nutrient management

\begin{tabular}{|c|c|c|c|}
\hline Treatments & 30 DAP & 60 DAP & 90 DAP \\
\hline \multicolumn{4}{|l|}{ Species (V) } \\
\hline $\mathrm{V}_{1}:$ Ocimum sanctum & 0.43 & 0.64 & 1.60 \\
\hline $\mathrm{V}_{2}$ : Ocimum grastissium & 1.35 & 3.23 & 4.46 \\
\hline SEd \pm & 0.03 & 0.07 & 0.13 \\
\hline $\mathrm{CD}(\mathbf{P}=\mathbf{0 . 0 5})$ & 0.06 & 0.14 & 0.26 \\
\hline \multicolumn{4}{|l|}{ Spacing (S) } \\
\hline$S_{1:} 40 \mathrm{~cm} \mathrm{X} 40 \mathrm{~cm}$ & 1.02 & 2.16 & 3.26 \\
\hline$S_{2}: 50 \mathrm{~cm} X 50 \mathrm{~cm}$ & 0.76 & 1.71 & 2.80 \\
\hline SEd \pm & 0.03 & 0.07 & 0.13 \\
\hline $\mathrm{CD}(\mathrm{P}=\mathbf{0 . 0 5})$ & 0.06 & 0.14 & 0.26 \\
\hline \multicolumn{4}{|l|}{$\begin{array}{l}\text { Integrated Nutrient } \\
\text { Management (F) }\end{array}$} \\
\hline$F_{1}: 6$ ton/ha Vermicompost & 0.63 & 1.14 & 2.06 \\
\hline $\begin{array}{l}\mathrm{F}_{2}: \text { 20-10-10 N-P }-\mathrm{O}_{5}-\mathrm{K}_{2} \mathrm{O} \\
\mathrm{kg} / \mathrm{ha}+\mathrm{VC}(3 \mathrm{t} / \mathrm{ha})\end{array}$ & 0.71 & 1.79 & 2.82 \\
\hline $\begin{array}{l}F_{3}: 40-15-15 \mathrm{~N}-\mathrm{P}_{2} \mathrm{O}_{5}-\mathrm{K}_{2} \mathrm{O} \\
\mathrm{kg} / \mathrm{ha}+\mathrm{VC}(3 \mathrm{t} / \mathrm{ha})\end{array}$ & 1.07 & 2.32 & 3.47 \\
\hline $\begin{array}{l}\mathrm{F}_{4}: \text { 60-20-20 N-P } \mathrm{P}_{2}-\mathrm{K}_{2} \mathrm{O} \\
\mathrm{kg} / \mathrm{ha}+\mathrm{VC}(3 \mathrm{t} / \mathrm{ha})\end{array}$ & 1.13 & 2.49 & 3.78 \\
\hline SEd \pm & 0.04 & 0.10 & 0.13 \\
\hline $\mathrm{CD}(\mathbf{P}=\mathbf{0 . 0 5})$ & 0.08 & 0.20 & 0.37 \\
\hline \multicolumn{4}{|l|}{ Interactions } \\
\hline $\mathbf{V} \times S$ & NS & NS & NS \\
\hline $\mathbf{S} \times \mathbf{F}$ & NS & NS & NS \\
\hline $\mathbf{V} \times \mathbf{F}$ & NS & NS & NS \\
\hline $\mathbf{V} \times S \times F$ & NS & NS & NS \\
\hline
\end{tabular}


Table.4 Dry weight of tulsi leaves (ton/ha) as influenced by species, Spacing and integrated nutrient management

\begin{tabular}{|c|c|c|c|}
\hline Treatments & 30 DAP & 60 DAP & 90 DAP \\
\hline \multicolumn{4}{|l|}{ Species (V) } \\
\hline $\mathrm{V}_{1}:$ Ocimum sanctum & 0.16 & 0.21 & 0.38 \\
\hline $\mathrm{V}_{2}:$ Ocimum grastissium & 0.35 & 0.92 & 1.27 \\
\hline SEd \pm & 0.01 & 0.03 & 0.04 \\
\hline $\mathrm{CD}(\mathrm{P}=\mathbf{0 . 0 5})$ & 0.02 & 0.06 & 0.08 \\
\hline \multicolumn{4}{|l|}{ Spacing (S) } \\
\hline$S_{1:} 40 \mathrm{~cm} X 40 \mathrm{~cm}$ & 0.28 & 0.63 & 0.91 \\
\hline$S_{2}: 50 \mathrm{~cm} \mathrm{X} 50 \mathrm{~cm}$ & 0.23 & 0.50 & 0.75 \\
\hline SEd \pm & 0.01 & 0.03 & 0.04 \\
\hline $\mathrm{CD}(\mathrm{P}=0.05)$ & 0.02 & 0.06 & 0.08 \\
\hline \multicolumn{4}{|l|}{$\begin{array}{l}\text { Integrated Nutrient } \\
\text { Management (F) }\end{array}$} \\
\hline$F_{1}: 6$ ton/ha Vermicompost & 0.16 & 0.36 & 0.55 \\
\hline $\begin{array}{l}\mathrm{F}_{2}: 20-10-10 \mathrm{~N}-\mathrm{P}_{2} \mathrm{O}_{5}-\mathrm{K}_{2} \mathrm{O} \\
\mathrm{kg} / \mathrm{ha}+\mathrm{VC}(3 \mathrm{t} / \mathrm{ha})\end{array}$ & 0.20 & 0.53 & 0.76 \\
\hline $\begin{array}{l}F_{3}: 40-15-15 \mathrm{~N}-\mathrm{P}_{2} \mathrm{O}_{5}-\mathrm{K}_{2} \mathrm{O} \\
\mathrm{kg} / \mathrm{ha}+\mathrm{VC}(3 \mathrm{t} / \mathrm{ha})\end{array}$ & 0.30 & 0.65 & 0.95 \\
\hline $\begin{array}{l}\mathrm{F}_{4}: \text { 60-20-20 N-P } \mathrm{O}_{5}-\mathrm{K}_{2} \mathrm{O} \\
\mathrm{kg} / \mathrm{ha}+\mathrm{VC}(3 \mathrm{t} / \mathrm{ha})\end{array}$ & 0.32 & 0.72 & 1.05 \\
\hline SEd \pm & 0.01 & 0.09 & 0.06 \\
\hline $\mathrm{CD}(\mathrm{P}=\mathbf{0 . 0 5})$ & 0.03 & 0.18 & 0.12 \\
\hline \multicolumn{4}{|l|}{ Interactions } \\
\hline $\mathbf{V} \times \mathbf{S}$ & NS & NS & NS \\
\hline $\mathbf{S} \times \mathbf{F}$ & NS & NS & NS \\
\hline $\mathbf{V} \times \mathbf{F}$ & NS & NS & NS \\
\hline $\mathbf{V} \times S \times F$ & NS & NS & NS \\
\hline
\end{tabular}


Table.5 Oil content and oil yield in tulsi as influenced by species, Spacing and integrated nutrient management

\begin{tabular}{|c|c|c|}
\hline Treatments & $\begin{array}{c}\text { Oil content } \\
(\%)\end{array}$ & $\begin{array}{c}\text { Oil yield } \\
\text { (kg/ha) }\end{array}$ \\
\hline \multicolumn{3}{|l|}{ Species (V) } \\
\hline $\mathrm{V}_{1}:$ Ocimum sanctum & 0.68 & 11.00 \\
\hline $\mathrm{V}_{2}:$ Ocimum grastissium & 0.66 & 29.60 \\
\hline SEd \pm & 0.02 & 0.82 \\
\hline $\mathrm{CD}(\mathrm{P}=0.05)$ & NS & 1.67 \\
\hline \multicolumn{3}{|l|}{ Spacing (S) } \\
\hline$S_{1:} 40 \mathrm{~cm} \mathrm{X} 40 \mathrm{~cm}$ & 0.67 & 21.84 \\
\hline$S_{2}: 50 \mathrm{~cm} \mathrm{X} 50 \mathrm{~cm}$ & 0.67 & 18.76 \\
\hline SEd \pm & 0.02 & 0.82 \\
\hline $\mathrm{CD}(\mathrm{P}=\mathbf{0 . 0 5})$ & NS & 1.67 \\
\hline \multicolumn{3}{|l|}{$\begin{array}{l}\text { Integrated Nutrient } \\
\text { Management (F) }\end{array}$} \\
\hline$F_{1}: 6$ ton/ha Vermicompost & 0.68 & 13.87 \\
\hline $\begin{array}{l}\mathrm{F}_{2}: \text { 20-10-10 N-P } \mathrm{O}_{5}-\mathrm{K}_{2} \mathrm{O} \\
\mathrm{kg} / \mathrm{ha}+\mathrm{VC}(3 \mathrm{t} / \mathrm{ha})\end{array}$ & 0.68 & 19.04 \\
\hline $\begin{array}{l}\mathrm{F}_{3}: 40-15-15 \mathrm{~N}-\mathrm{P}_{2} \mathrm{O}_{5}-\mathrm{K}_{2} \mathrm{O} \\
\mathrm{kg} / \mathrm{ha}+\mathrm{VC}(3 \mathrm{t} / \mathrm{ha})\end{array}$ & 0.67 & 23.11 \\
\hline $\begin{array}{l}\mathrm{F}_{4}: \text { 60-20-20 N-P } \mathrm{O}_{5}-\mathrm{K}_{2} \mathrm{O} \\
\mathrm{kg} / \mathrm{ha}+\mathrm{VC}(3 \mathrm{t} / \mathrm{ha})\end{array}$ & 0.67 & 25.19 \\
\hline SEd \pm & 0.03 & 1.15 \\
\hline $\mathrm{CD}(\mathrm{P}=\mathbf{0 . 0 5})$ & NS & 2.36 \\
\hline \multicolumn{3}{|l|}{ Interactions } \\
\hline $\mathbf{V} \times S$ & NS & NS \\
\hline $\mathbf{S} \times \mathbf{F}$ & NS & NS \\
\hline $\mathbf{V} \times \mathbf{F}$ & NS & NS \\
\hline $\mathbf{V} \times S \times F$ & NS & NS \\
\hline
\end{tabular}


The superior growth performance of Tulsi in these nutrient management practices was due to higher availability of nutrients, where the gradual increase in nutrient improved the availability of nutrients from planting to harvest. These results are similar to that of the findings by Basavaraju et al., (2012).

\section{Yield attributes}

There was significant difference between the species in respect of fresh and dry leaves yield. Ram Tulsi produced significantly higher fresh leaves yield than that of Black Tulsi. It might be due to the genetic character. Ram Tulsi had bigger leaves and more foliage growth than that of Black Tulsi.

Spacing had significant effect on fresh and dry leaves yield. The closer spacing $(40 \times 40 \mathrm{~cm})$ recorded higher yield than that of wider spacing $(50 \times 50 \mathrm{~cm})$. In closer spacing, more number of plants could be accommodated. As such, it produced more leaves per unit area. Similar results also have been reported by Raina et al., (2013), Arabaci et al., (2004), Ram et al., (2002).

Integrated nutrient management practices had significant effect on fresh and dry leaves yield at different growth stages of the plant. N, P and $\mathrm{K}$ are the major nutrients required for plant growth. $\mathrm{N}$ is the major constituent of chlorophyll that serves for photosynthesis. $\mathrm{P}$ is also major binding block of nucleic acid and $\mathrm{K}$ plays a very important role in the regulation of metabolic activities in plants. A gradual increase in fertilizer doses with certain amount of Vermicompost increases the fresh and dry leaves yield gradually. Application of $60-20-20 \mathrm{~N}-\mathrm{P}_{2} \mathrm{O}_{5}-\mathrm{K}_{2} \mathrm{O} \mathrm{kg} / \mathrm{ha}+$ $3 \mathrm{t} /$ ha Vermicompost $\left(\mathrm{F}_{4}\right)$ resulted in highest fresh and dry leaves yield among the four treatments which was, statistically at par with 40-15-15 N-P $\mathrm{O}_{5}-\mathrm{K}_{2} \mathrm{O} \mathrm{kg} / \mathrm{ha}+3 \mathrm{t} / \mathrm{ha}$ Vermicompost $\left(\mathrm{F}_{3}\right)$ and greater than that of
20-10-10 N-P $\mathrm{O}_{5}-\mathrm{K}_{2} \mathrm{O} \mathrm{kg} / \mathrm{ha}+3 \mathrm{t} / \mathrm{ha}$ Vermicompost $\left(\mathrm{F}_{2}\right)$ and (6ton/ha Vermicompost $\left(\mathrm{F}_{1}\right)$. Higher fresh and dry leaves could be attributed to better growth and dry matter accumulation, which is due to enhanced availability and uptake of nutrients. Almost similar results have been reported by Anwar et al., (2005), Singh and Ramesh (2002), Arularasu et al., (2008).

Oil content of Tulsi did not differ significantly due to the effect of species, spacing and Integrated Nutrient Management. This result is agreement with the findings obtained by Asthana and Gupta (1984) and Dey and Choudhuri (1984). However, oil yield had significantly influenced by species, spacing and Integrated nutrient management because oil yield is directly related with the leaves yield. Ram tulsi had significantly higher oil yield than that of Krishna tulsi, due to higher leaf yield (Table 5).

Narrow spacing $(40 \times 40 \mathrm{~cm})$ was found to produce more oil yield than that of wider spacing $(50 \times 50 \mathrm{~cm})$. This might be due to more yield of leaves under wider spacing which ultimately influenced the oil yield. Similar results were observed by Arabaci et al., (2004). Raina et al., (2013)

Oil yield had significantly differed for different nutrient doses. Application of 6020-20 N-P $2 \mathrm{O}_{5}-\mathrm{K}_{2} \mathrm{O} \mathrm{kg} / \mathrm{ha}+3 \mathrm{t} / \mathrm{ha}$ Vermicompost $\left(\mathrm{F}_{4}\right)$ had highest oil yield followed by $40-15-15 \mathrm{~N}-\mathrm{P}_{2} \mathrm{O}_{5}-\mathrm{K}_{2} \mathrm{O} \mathrm{kg} / \mathrm{ha}+$ $3 \mathrm{t} /$ ha Vermicompost $\left(\mathrm{F}_{3}\right), 20-10-10 \quad \mathrm{~N}^{-} \mathrm{P}_{2} \mathrm{O}_{5^{-}}$ $\mathrm{K}_{2} \mathrm{O} \mathrm{kg} / \mathrm{ha}+3 \mathrm{t} / \mathrm{ha}$ Vermicompost $\left(\mathrm{F}_{2}\right)$ and 6ton/ha Vermicompost $\left(\mathrm{F}_{1}\right)$. Higher doses of $\mathrm{N}$ increase the methyl chavicol content in the oil. Moreover, higher doses of nutrients yield more foliage which directly increases the oil content. Similar results were also reported by Basavaraju et al.(2012), Singh and Ramesh (2002). 


\section{References}

Anwar, M.; Patra, D. D.; Chand, S. and Kumar, A. 2005. Effect of Organic Manures and Inorganic Fertilizer on Growth, Herb and Oil Yield, Nutrient Accumulation, and Oil Quality of French Basil. Communications in Soil Science and plant analysis, 36: 13-14.

Arabaci, O. and Bayram, E. (2004). The effect of Nitrogen fertilization and different plant densities on some agronomic and technological characteristics of (Ocimum basilicum L.) Journal of Agronomy, 3(4): 255262.

Arularasu, P., Sambandamurth, S., Palanikumar, M. And Rajangam, J. 2008. Response of Nitrogen fertilization and spacing on growth and herbage yield of sacred basil (Ocimum sanctum $L)$. Indian Perfumer 52: 56-60.

Asthana, O. P. and Gupta, R. S. 1984. Effect of $\mathrm{N} P$ levels on physiological parameters at 3 growth stages in sacred basil (Ocimum sanctum Linn.). Indian Perfumer, 28(1): 49-53.

Basavaraju, T. B.; Nanjappa, H. V. and
Umesh, K. 2012. Influence of integrated Nutrient Management practices on growth and yield of Holy Basil (Ocimum sanctum L.) Intercropped with coconut. Mysore Journal of Agricultural Science, 46(3): 567-572.

Dey, B. B. and Choudhari, M. A. 1984. Effect of application of $\mathrm{N}, \mathrm{P}$ and $\mathrm{K}$ on growth and yield of essential oil and eugenol in (Ocimum sanctum L.). Pafai J. 6: 20-24.

Raina, n. s.; Rafiq, M.; Sood, k. k.; Bali, a.s.; Gupta, s. k. and Sehgal S. 2013. Growth and yield of Ocimum sanctum in response to integrated nutrient management and plant spacing. Indian Journal of Agronomy, 58(1): 129-132

Ram, M., Ram, D., Naqvi, A.A. and Kumar, S.2002. Effect of plant density and harvesting time on the yield and the quality of essential oil in Ocimum species. Journal of Medicinal and aromatic plant Sciences 24: 393-96.

Singh M. and Singh, R. 2002. Response of sweet basil (Ocimum basilicum) to organic and inorganic fertilizer in semiarid tropical conditions. Journal of Medicinal and Aromatic Plant Sciences, 24:947-950

\section{How to cite this article:}

Bhaba Prashad Kalita, Prabin Kumar Gogoi, Abhijit Sarma, Iswar Chandra Barua and Borsha Neog. 2018. Effect of Integrated Nutrient Management and Different Plant Spacing on Tulsi. Int.J.Curr.Microbiol.App.Sci. 7(02): 1352-1361. doi: https://doi.org/10.20546/ijcmas.2018.702.164 